\title{
Phytoplankton composition of the urban man-made lakes of Yamoussoukro (Côte d'Ivoire)
}

\author{
Nangoh Kouamé Martin ${ }^{1 *}$, Adon Marie Paulette², Edia Oi Edia1 ${ }^{1}$ Niamien-Ebrottié Julie Estelle, \\ Ouattara allassane ${ }^{1}$ \\ 1 Laboratory of Environment and Aquatic Biology, Nangui Abrogoua University, 02 P.O BOX 801, Abidjan 02, Côte \\ d'Ivoire \\ 2Formation and Research Unit of Environment and Agroforestry, University of Jean Lorougnon Guedé of Daloa, P.O \\ BOX 150, Daloa, Côte d'Ivoire \\ *Corresponding author: nangohkmartin@gmail.com , Telephone: (225)07453691
}

Original submitted in on $28^{\text {th }}$ May 2019. Published online at www.m.elewa.org/journals/ on $31^{\text {st }}$ August 2019 https://dx.doi.org/10.4314/jab.v140i1.7

\begin{abstract}
Objective: Spatial and seasonal variations of phytoplankton composition in the urban man-made lake of Yamoussoukro city has been analysed to identify the most representative species of these polluted urban lake.

Methodology and results: The composition of phytoplankton assemblage in urban man-made lakes of Yamoussoukro City were investigated from December 2015 to October 2017 on a bi-monthly basis, at 28 stations on 8 lakes. One hundred and Ninety six (196) phytoplankton taxa were identified representatives of 63 genera, 33 families, 17 orders, 8 classes and 5 phyla. Most of these genera belong to Chlorophyta (34.8 $\%)$ followed by Euglenophyta (30.39 \%) next Cyanobacteria (19.11\%), Bacillariophyta (14.16\%) and Dinophyta (0.9\%). The Genera Trachelomonas (23 taxa), Scenedesmus (20 taxa), Phacus (16 taxa), Lepocinclis (9 taxa) were found to be dominant (>10\%) in phytoplankton taxonomic richness. The greatest species richness was found in the lake 5 (99 taxa) and the smallest was recorded in the lake 7 (9 taxa).

Conclusion and application of results: This study revealed a first inventory of phytoplankton taxa of the Yamoussoukro's urban man-made lakes and proposes a pattern of the spatio-temporal variability of the phytoplankton community. The lakes were rich in the number of taxa (196), because the waters of the lake are stagnant. Chlorophyta and Euglenophyta dominated the phytoplankton communities. The highest number of taxa (99) was recorded in the lake 5, while the lowest number of taxa (10) was found in the lake 7. The best represented genus are by order of importance, Trachelomonas (23 taxa) scenedesmus (20 taxa), Phacus (16 taxa) and Lepocinclis (9 taxa). The results of the study of phytoplankton in Yamoussoukro urban lakes could serve as references to evaluate the ecological health of water bodies.
\end{abstract}

Key words: phytoplankton, urban man-made lake, taxonomic richness, Yamoussoukro.

\section{INTRODUCTION}

Eutrophication still represents a major problem worldwide (Ansari et al. 2011). Reservoirs are often inherently unable to supply safe and clean drinking water (Naselli-Flores, 2011, 2014), and expensive treatments are required to ensure adequate water supply for domestic uses. One of the consequences of eutrophication is the proliferation of planktonic cyanobacteria, which 
impair water quality because of their actual or potential toxicity (Paerl et al. 2011). The onset of eutrophication causes an increase in phytoplankton biomass, but the composition of the phytoplankton community becomes uniform. Some species disappear, while at the same time, opportunistic species of phytoplankton begin to dominate (McQuatters- Gollop et al. 2009). At this point, species diversity is decreases because of the competitive exclusion between species, whereas with a slight increase in eutrophication, competition is relaxed, thus resulting in increased diversity. With a further increase in eutrophication, diversity reduces again and this time, because of the decrease in species due to stress (Spatharis et al. 2007). Eutrophication tends to favour small and fast-growing organisms, which implies that the proportion of the dominant taxa to the total biomass is relatively low, in others words, species the diversity higher than when large-sized taxa dominate (Uusitalo et al. 2013). In Côte d'Ivoire,

\section{MATERIALS AND METHODS}

Study area and sampling stations: Yamoussoukro (the political capital of Côte d'Ivoire is located geographically between $6^{\circ} 40^{\prime}$ and $7^{\circ} 00^{\prime} \mathrm{N}$, and $5^{\circ} 10^{\prime}$ and $5^{\circ} 20^{\prime} \mathrm{W}$ (Fig 1). The capital has a total 31 lakes, ten of which are man-made lakes. These lakes communicate with each other by gravity and form a complex system covering approximately 140 ha with a catchment area close to $28.5 \mathrm{~km}^{2}$. This study was carried out on seven (7) of the man-made lakes (lake 1 , lake 5, lake 6, lake 7, lake 8, lake 9 and lake 10) and one natural lake (lake 0 ). These urban man-made lakes receive wastewater and solid waste from various human activities (domestic wastewater and solid waste, the majority of small surface reservoirs are presently considered to be threatened. Urban lakes of Yamoussoukro are not left out. Originally, these lakes had been created to serve drainage sites and added aesthetic value for the city. The misuse (practice of agriculture on the banks and discharge of solid and liquid waste), however, of these lakes has led to their eutrophication. Many studies have been conducted on these urban manmade lake of Yamoussoukro, relating to sediments fluxes (Kouakou et al. 2014), birds (Konan et al. 2015; Konan et al. 2014), eutrophication (Parinet et al. 2010), and anthropogenic pollution (N'guessan, 2011). There is much study, however, on the aquatic community in general and in particular the algae of these waters. Therefore, this paper study intends to investigate spatial and seasonal variations of phytoplankton composition in the urban man-made lake of Yamoussoukro city to bridge the existing knowledge gap.

urban agriculture, schools, hospitals, hotels, restaurants, military camps, car washing services, car garages, gas stations, cattle rearing activities,...) which make them eutrophic. Originally designed to beautify the city, $70 \%$ of the man-made lakes of are currently invaded by macrophytes (N'guessaan et al. 2011). The samples were collected from twenty-eight (28) stations chosen approximately $3 \mathrm{~m}$ from the water's edge. The number of sites per lakes depends of its surface area. Therefore, seven sampling sites were defined on Lake 5 , four on lakes 0 and 1, three on lakes 6,8 and 9 and two on lakes 7 and 10 (Fig. 1). 


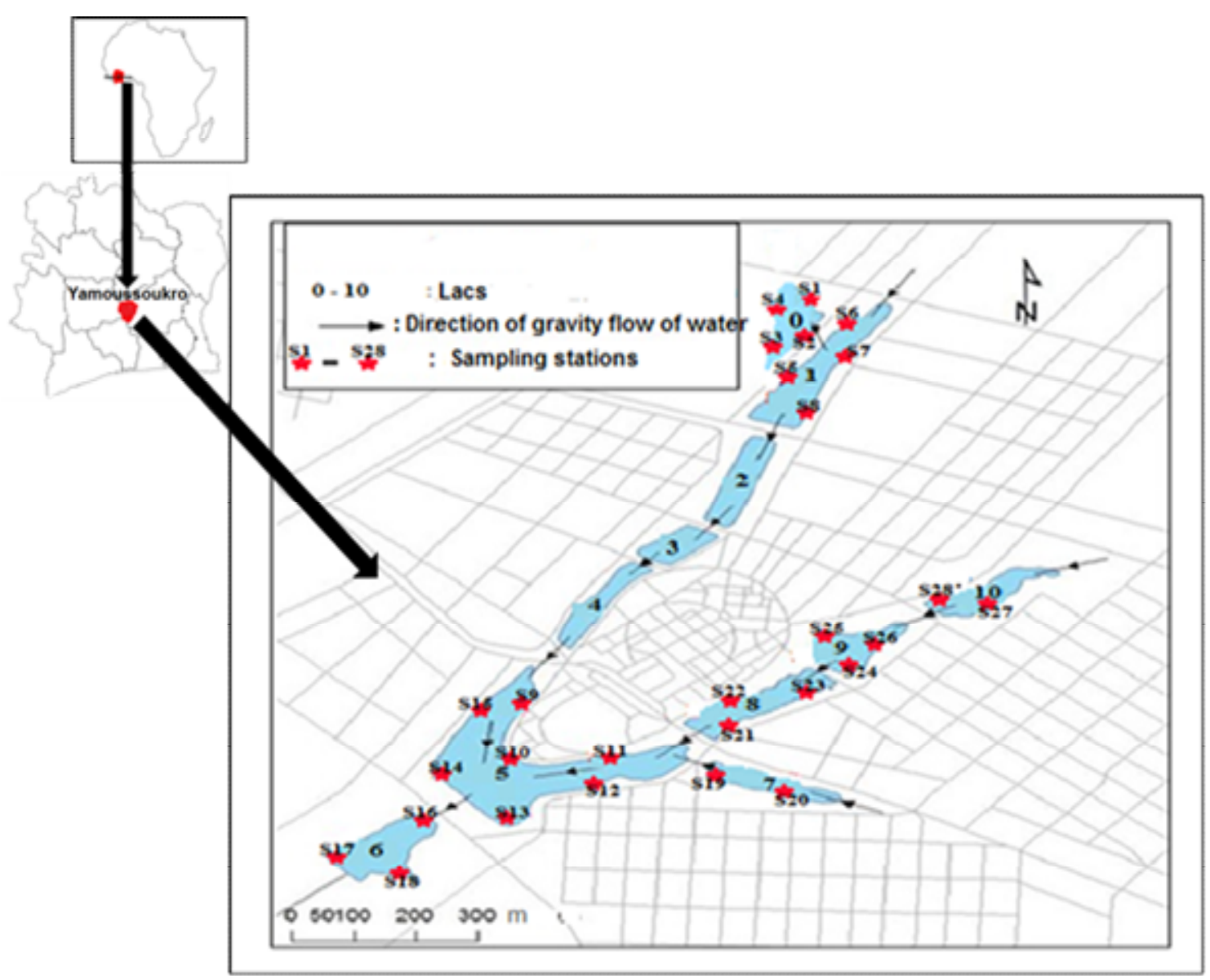

Figure 1: The map of Yamoussoukro City showing the study lakes and sampling stations

Sampling and identification of phytoplankton: Samples were collected from December 2015 to November 2017 at 28 stations in the 7 urban manmade lakes and one natural lake. Sampling was bimonthly and samples collected from each lake's stations were mixed into a single sample. The samples are grouped into the four climatic seasons. December to February for the long dry season (LDS), March to July for the long rainy season (LRS), August to September for the short dry season (SDS) and October to November for the short rainy season (SRS). For each sample, a multiparameter HQ40d was used to measure water temperature, conductivity, dissolved oxygen and $\mathrm{pH}$. For nutrients (nitrates, nitrites ammonium salt and orthophosphates), samples of 500 $\mathrm{ml}$ were collected and refrigerated for later analysis at laboratory following the spectrometric method (AFNOR, 2005). The turbidity of the water was measured by a Secchi disk. Samples for phytoplankton composition determination, were collected from surface water using a plankton net $(20 \mu \mathrm{m}$ mesh, $0.64 \mathrm{~m}$ radius coupled with a collector) and fixed with $5 \%$ formaldehyde. For species identification, phytoplankton samples were examined in the laboratory using a Carl Zeiss microscope equipped with a calibrated micrometer. The algal classification scheme proposed by van den Hoek et al. (1995) was adopted. Identification of the phytoplankton taxa was made with reference to works to Desikachary (1959) and Komárek and Anagnostidis (2005) (Cyanobacteria), Huber-Pestalozzi (1955) (Euglenophyta), Komárek and Frott (1983) (Chlorophyta), Krammer and Lange-Bertalot (1988, 1991), Tomas (1995) (Bacillariophyta) and Von Stosch (1969) Dinophyta.

Data analyses: Differences of physico-chemical parameters among sampling seasons and lake were tested using ANOVA (significance level 0.05). For this analysis the Turkey test was used for the two by two comparison in case the variables show a difference $(p<$ 0.05 ) between the groups (lakes, seasons). However, means and standard deviation of all measurements were recorded for each parameter. The coefficient of variation (CV \%) was computed according to Zar (1999) : 
$C V(\%)=\frac{\sigma}{\mu} \times 100$

Where $\sigma$ the standard deviation and $\mu$ is the mean of the measurements of each parameter.

According to the value of $\mathrm{CV}$, three categories of variations are highlighted:

- If CV is inferior to $2 \%$, there is very little variation in the parameter

- $\quad$ If CV is between 2 and $25 \%$, the parameter variation is low

- $\quad$ If CV is superior to $25 \%$, the parameter varies greatly. The similarity between two communities (habitats) was estimated by Jaccard's similarity index. According to Schaeffer et al (2005), this index varies from 0 (no similarity) to 1 (identical environments). The formula is the following

$c_{j}=\frac{j}{a+b-j}$

$c_{j}$ : similarity index of Jaccard

a: the number of taxa specific to lake 0

\section{RESULTS}

Physico-chemical variables of the lakes: The measured physico-chemical variables at all eight sampling lakes are presented in Table 1. The mean values $(0.21 \mathrm{mg} / \mathrm{l})$, of the orthophosphate, dissolved oxygen $(8.27 \mathrm{mg} / \mathrm{l}), \mathrm{pH}$ (8.62) and ammonium $(0.98 \mathrm{mg} / \mathrm{l})$ were slightly higher at the lake 8 , than the others lakes. In addition, turbidity presented the highest values at lake $10(30.09 \mathrm{~cm})$ and the highest value of temperature was recorded at the lake $9\left(30.55^{\circ} \mathrm{C}\right)$. Finally, the mean values of conductivity $(965 \mu \mathrm{S} / \mathrm{cm})$, nitrates $(22.10 \mathrm{mg} / \mathrm{l})$ and nitrite $(0.08 \mathrm{mg} / \mathrm{l})$ were high at the lake 7. Dissolved oxygen, turbidity, orthophosphate, nitrate $\mathrm{b}$ : the number of taxa specific to Lake 1 $\mathrm{j}$ : the number of species common to both lakes Grouping of phytoplankton species in terms of frequency coefficient was used following frequency groups to show the presence frequency of species in the community during the year. Three frequency groups were noted according to value of $F$ (Dajoz, 2000) $\mathrm{F}>50 \%$ : continuous species; $25 \%<\mathrm{F}<50 \%$ : common species; $F<25 \%$ : rare species in the community. Frequency was calculated with the following equality:

$F=\frac{F i}{F t} \times 100$

$F_{i:}$ presence number of i species in total sampling; $F_{t}=$ : total number of sampling of whole

Species.

Then, hierarchical cluster analysis (HCA) was carried out from the values of Jaccard similarity index calculated between the lakes. The analyses were performed using Past 3.0.

and ammonium showed high coefficient of variation values (CV > 25\%). Concerning nitrite, only Lake 8 not presented high variability. The parameters as temperature, conductivity and $\mathrm{pH}$ in the eight sampling sites were similar (CV $<25 \%$ ), .Turbidity displayed a high variability (CV > 25\%) at the lakes 1 and 10. There was significant differences in the physico- chemical parameters such as temperature, dissolved oxygen, nitrites and orthophosphate between the eight lakes (turkey test; $p<0.05$ ). 
Table 1: Mean and coefficient of variation (CV) of the physico-chemical variables in Yamoussoukro's urban man-made lakes (L0 - L10).

\begin{tabular}{|c|c|c|c|c|c|c|c|c|c|c|c|c|c|c|c|c|}
\hline \multirow[b]{2}{*}{ variables } & \multicolumn{2}{|l|}{ LO } & \multicolumn{2}{|l|}{$\mathrm{L} 1$} & \multicolumn{2}{|l|}{ L5 } & \multicolumn{2}{|l|}{ L6 } & \multicolumn{2}{|l|}{ L7 } & \multicolumn{2}{|l|}{ L8 } & \multicolumn{2}{|l|}{ L9 } & \multicolumn{2}{|l|}{ L10 } \\
\hline & Mean & CV (\%) & Mean & CV (\%) & Mean & $\begin{array}{l}\text { CV } \\
(\%)\end{array}$ & Mean & $\begin{array}{l}\text { CV } \\
(\%)\end{array}$ & Mean & CV (\%) & Mean & $\begin{array}{l}\text { CV } \\
(\%)\end{array}$ & Mean & CV (\%) & Mean & CV $(\%)$ \\
\hline $\mathrm{T}\left({ }^{\circ} \mathrm{C}\right)$ & $27.87 a$ & 3.50 & $27.67 a$ & 5.65 & $28.82 a$ & 4.06 & $27.21 \mathrm{a}$ & 5.37 & $28.02 a$ & 9.63 & $30.17 a$ & 7.95 & $30.55 a$ & 2.83 & $28.15 a$ & 2.96 \\
\hline $\begin{array}{l}\text { Conductivity } \\
(\mu \mathrm{S} / \mathrm{cm})\end{array}$ & $\begin{array}{l}344.29 \\
\text { ac }\end{array}$ & 15.92 & $\begin{array}{l}383.82 \\
a b\end{array}$ & 6.70 & $\begin{array}{l}441.52 \\
b\end{array}$ & 5.08 & $\begin{array}{l}435.87 a \\
b\end{array}$ & 7.71 & $\begin{array}{l}965.22 \\
c\end{array}$ & 3.70 & $\begin{array}{l}412.17 \\
\mathrm{~b}\end{array}$ & 7.26 & $\begin{array}{l}369.87 \\
a b\end{array}$ & 21.99 & $\begin{array}{l}293.87 \\
a b\end{array}$ & 12.92 \\
\hline $\mathrm{pH}$ & $6.74 a$ & 2.77 & $6.75 a b$ & 12.22 & $\begin{array}{l}7.41 a b \\
c\end{array}$ & 7.92 & $7.56 \mathrm{bc}$ & 5.78 & $8.14 \mathrm{c}$ & 6.56 & $8.62 \mathrm{C}$ & $8.74 \mathrm{c}$ & $8.34 c$ & 6.67 & $8.30 \mathrm{~d}$ & 5.57 \\
\hline $\begin{array}{l}\text { dissolved oxygen } \\
\text { (mg/L) }\end{array}$ & $2.05 a$ & 52.00 & $1.82 \mathrm{a}$ & 60.08 & $5.65 a$ & 29.35 & $1.10 a$ & 70.02 & $4.35 a$ & 97.50 & $8.27 a$ & 52.14 & $5.67 a$ & 49.70 & $3.87 a$ & 111.32 \\
\hline Turbidity(cm) & $25.12 a$ & 20.06 & $20.65 a$ & 30.39 & $25.5 a$ & 14.09 & $25.65 a$ & 24.28 & $16.43 b$ & 10.70 & $22.20 a$ & 12.18 & $27.2 a$ & 11.84 & $30.09 a$ & 27.51 \\
\hline Orthophosphate(mg/L) & $0.07 a$ & 86.85 & $0.05 a$ & 44.65 & $0.11 a$ & 64.39 & $0.12 a$ & 33.62 & $0.07 a$ & 30.58 & $0.21 a$ & 83.59 & $0.06 \mathrm{a}$ & 95.92 & $0.07 a$ & 99.65 \\
\hline Nitrate(mg/L) & $4.60 \mathrm{a}$ & 19.84 & $4.37 a$ & 15.76 & $9.10 \mathrm{ab}$ & 45.13 & 12.95ab & 56.50 & $\begin{array}{l}22.10 a \\
b\end{array}$ & 69.31 & $\begin{array}{l}11.95 a \\
b\end{array}$ & 47.79 & $5.97 a b$ & 15.05 & $6.40 \mathrm{~b}$ & 9.37 \\
\hline Nitrite(mg/L) & $0.02 \mathrm{a}$ & 54.79 & $0.05 a$ & 160.07 & $0.03 a$ & 31.79 & $0.019 a$ & $\begin{array}{l}124.4 \\
7\end{array}$ & $0.08 a$ & 88.48 & $0.018 a$ & 19.16 & $0.01 a$ & 40 & $0.01 \mathrm{a}$ & 61.44 \\
\hline Ammonium(mg/L) & $0.19 a$ & 118.48 & $0.10 a$ & 34.14 & $0.15 a b$ & 93.80 & $0.88 a b$ & $\begin{array}{l}162.3 \\
2\end{array}$ & $0.60 \mathrm{a}$ & $\begin{array}{l}136.33 \\
a\end{array}$ & $0.98 a b$ & $\begin{array}{l}177.7 \\
3\end{array}$ & $0.11 a$ & 43.60 & 0.07 & 79.10 \\
\hline
\end{tabular}

The letters indicate the significant difference between variables (Tukey test, $p<0.05$ ). There is no significant difference between the mean with suffix a on the same row (Tukey test, $p>0.05$ )

Table 2. Mean of physico-chemical variables and their coefficient of variation (CV) in Yamoussoukro's urban man-made lakes at different periods

\begin{tabular}{|c|c|c|c|c|c|c|c|c|}
\hline \multirow[b]{2}{*}{ variables } & \multicolumn{2}{|l|}{ LDS } & \multicolumn{2}{|l|}{ SDS } & \multicolumn{2}{|l|}{ LRS } & \multicolumn{2}{|l|}{ SRS } \\
\hline & Mean & CV $(\%)$ & Mean & CV (\%) & Mean & CV $(\%)$ & Mean & CV $(\%)$ \\
\hline $\mathrm{T}\left({ }^{\circ} \mathrm{C}\right)$ & $27.36 a$ & 7.34 & $28.17 a$ & 6.44 & $28.93 a$ & 3.62 & $29.76 a$ & 5.76 \\
\hline Conductivity $(\mu \mathrm{S} / \mathrm{cm})$ & $444.89 a$ & 45.52 & $490.26 a$ & 44.35 & $454.38 \mathrm{a}$ & 48.19 & $433.78 a$ & 50.15 \\
\hline $\mathrm{pH}$ & $7.57 a$ & 7.06 & $7.42 \mathrm{a}$ & 14.11 & $7.67 a$ & 9.01 & $8.27 a$ & 11.57 \\
\hline dissolved oxygen (mg/L) & $3.88 a$ & 76.83 & $3.35 a$ & 106.33 & $5.27 a$ & 65.69 & $3.88 a$ & 105.69 \\
\hline Turbidity(cm) & $19.30 \mathrm{a}$ & 17.14 & $25.03 b$ & 24.48 & $24.59 b$ & 18.80 & $27.5 b$ & 25.48 \\
\hline Orthophosphate (mg/L) & $0.08 a$ & 50.18 & $0.05 a$ & 70.13 & $0.05 a$ & 46.78 & $0.19 b$ & 67.04 \\
\hline Nitrate(mg/L) & $12.92 a$ & 71.47 & $12.73 a$ & 94.59 & $6.7 a$ & 34.72 & $6.36 \mathrm{a}$ & 40.53 \\
\hline Nitrite(mg/L) & $0.01 a b$ & 56.77 & $0.06 \mathrm{~b}$ & 104.20 & $0.01 a$ & 47.70 & $0.035 b$ & 132.56 \\
\hline Ammonium(mg/L) & $0.22 a$ & 72.69 & $0.08 \mathrm{a}$ & 55.57 & $0.09 a$ & 92.70 & $1.15 a$ & 126.66 \\
\hline
\end{tabular}

$\mathrm{CV}$ : coefficient of variation. The letters indicate the significant difference between variables (Tukey test, $p<0.05$ ). There is no significant difference between the mean with suffix-a on the same row (Tukey test, $p>0.05)$; LRS: long rainy season; SDS: short dry season; SRS: short rainy season; LDS: long dry season. 
In this study, there were significant differences in turbidity between the long dry season and the others seasons $(p<0.05)$. Orthophosphate showed significant seasonal variation between short rainy season and the others seasons $(p<0.05)$. For nitrites, significant variation was observed between all seasons $(p<0.05)$, except between the long rainy season and the long dry season and between the short rainy season and the short dry season. Variables such as temperature, conductivity, $\mathrm{pH}$, dissolved oxygen, ammonium and nitrate do not vary significantly between seasons (turkey test; $p>0.05$ ) (Table 2). Temperature, $\mathrm{pH}$, ammonium, orthophosphate and turbidity recorded the highest values during short rainy season, conductivity and nitrite showing increased during short dry season. However, nitrate was high in the long dry season and dissolved oxygen presented high values in the long rainy season. The lower concentrations of salts ammonium, $\mathrm{pH}$ and dissolved oxygen were observed during the short dry season. Orthophosphates was low during the short rainy season. The Conductivity, temperature, nitrite and turbidity were low during long dry season and nitrates were low during long rainy season. Conductivity, nitrites, salts ammonium, nitrites, orthophosphates dissolved oxygen displayed a high variability (CV > 25\%) between all the seasons. Turbidity showed a high variability during the short rainy season (CV > 25\%).

Phytoplankton community: The analysis of phytoplankton composition at the investigated urban man-made lake of Yamoussoukro provided 196 phytoplankton taxa representative of 63 genera, 33 families, 17 orders, 8 classes and 5 phyla. Most of these species belong to Chlorophyta (34.8\%) followed Euglenophyta by $(30.39 \%)$ next Cyanobacteria (19.11 $\%)$, Bacillariophyta $(14.16 \%)$ and Dinophyta $(0.9 \%)$ (Fig.2). In terms of number of species, Chlorophyta and Euglenophyta are the most diverse. They are followed by Cyanobacteria and Bacillariophyta. Among Chlorophyta, the order of Chlorococcales (65 taxa) is the most diverse. At the level of this order the best represented genus are in decreasing order, Scenedesmus (20 taxa), Monoraphidium and Pediastrum (6 taxa) and Tetraedron (5 taxa). The Euglenophyta consists solely of the order of the Euglenales. This order is mainly represented by taxa of the genera Trachelomonas (23 taxa), Phacus (16 taxa), Lepocinclis (9 taxa) and Euglena (8 taxa). Of the 40 taxons of Cyanobacteria recorded, 23 taxa belong to the order of Hormogonal and 15 taxa to the order of Chroococcal. The best-represented genera are Oscillatoria (7 taxa) then Merismopedia and Pseudanabaena (5 taxa each). The number of Baccillariophyta species is low compared to the first three groups. In this branch, the genera Pinnularia (7 taxa) and Gomphonema (3 taxa) contain the largest number of taxa. The branch of Dinophyta is represented only by the genus Peridinium. The highest number of taxa (99) was recorded in the lake 5 , while the lowest number of taxa (10) was found in the lake 7. 26 taxa were recorded in lake 10, 39 taxa in lake 0,46 taxa in lake 0 and 9,55 taxa in lake 6 and 62 taxa in lake 8 . The similarity expressed by the Jaccard index indicates that the phytoplankton composition of lakes $5,6,8,9$ and 10 have a certain affinity between them (Cj: 0.3-0.45), lakes 0 and 1 have a floristic affinity (Cj: 0.3 ) and lake 7 has no affinity with another lake. The distribution of the lakes makes by the ascending hierarchical classification made from the values of Jaccard similarity index calculated between the different lakes, it possible to specify more or less the similarities or the differences in their algal composition. The dendogramm delimits the lakes in three groups (Fig.3). Group I pooled together lakes 0 and 1, they are moderately rich in taxa and Euglenophyta dominates the algal composition. The second group includes the lake 7 a low number of taxa characterizes this lake. Group III consists of lakes 5,6,8,9 and 10 located in the center of city whose phytoplankton composition are relatively rich in Chlorophyta. 


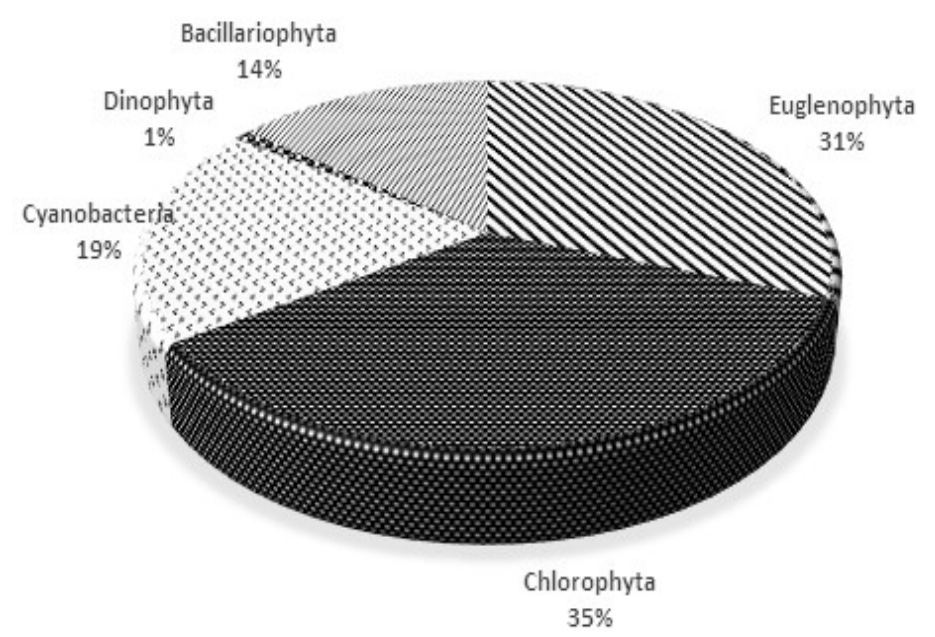

Figure 2: Relative taxonomic richness of phytoplankton in the urban man-made lakes of Yamoussoukro

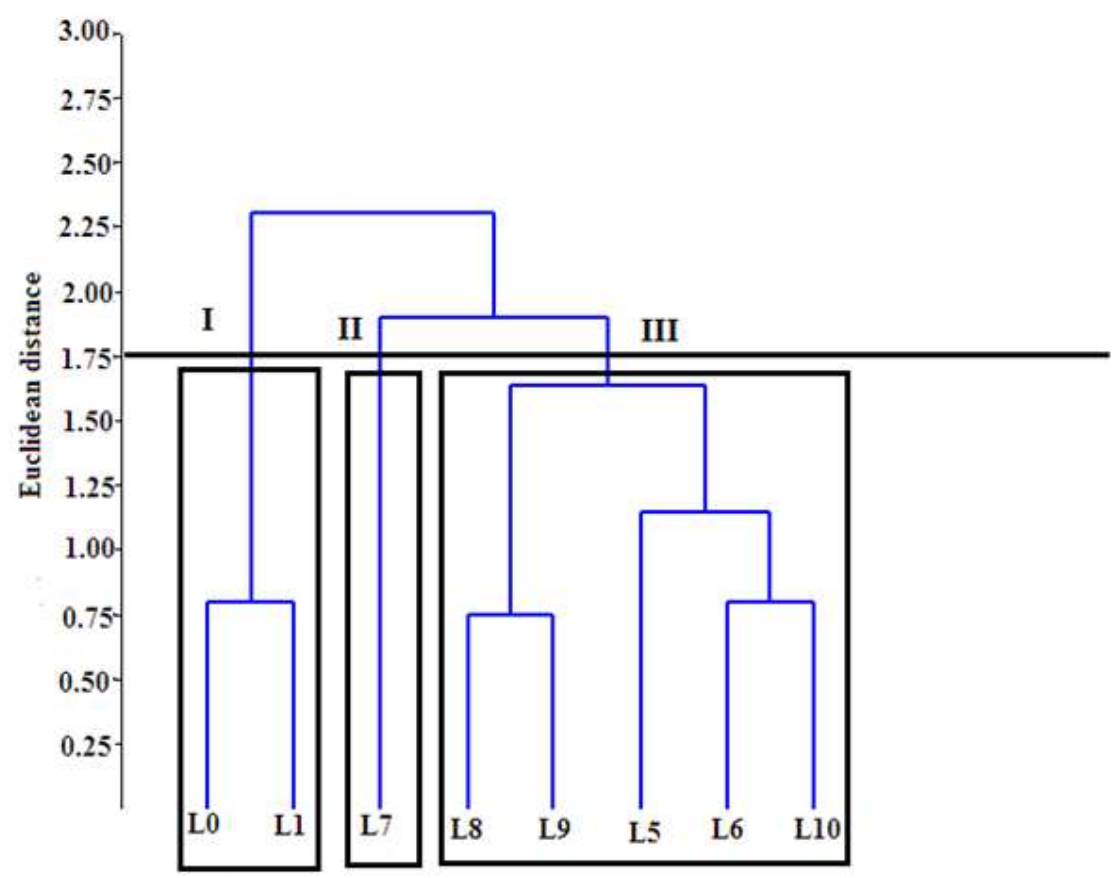

Figure 3: Dendogram showing the taxonomic similarities between lakes: LO- L10: codes of lakes, I, II and III: constituted groups

The distribution of species, constantly present in the different groups formed by HCA is summarized in table 3. Group I comprises 18 of these taxa, with 10 Euglenophyta, 3 Chlorophyta and 3 Bacillariophyta and 2 taxa belong to Cyanobacteria. Concerning group II, we have 5 taxa, constantly present: two Bacillariophyta and Euglenophyta and one Cyanobacteria. The group III is best structured with 29 taxa constantly present: these are 8 Chlorophyta, 7 Euglenophyta, 7 Bacillariophyta and 7 Cyanobacteria. 2 taxa were common in the three groups (Trachelomonas volvocina and Lepocinclis fusiformis). The groups II and I have 2 constant taxa, the groups III and I have 9 taxa common and the groups II and III have 5 taxa common.

Spatio-temporal patterns of phytoplankton in the lakes: The temporal variation of the different phytoplankton groups indicates a clear predominance of Chlorophyta and Euglenophyta (Fig.4) followed by Cyanobacteria, Bacillariophyta and Dinophyta that represent only between 0 and $19 \%$ of the total 
taxonomic richness. The Cyanobacteria, Bacillariophyta and Dinophyta constitute unessential taxa in all sampling stations and seasons. Their numbers are between 1 and 11 taxa for Bacillariophyta, between 0 and 2 taxa for Dinophyta and between 0 and 7 for Cyanobacteria, with the exception of Lake 5, where Cyanobacteria are permanent at all seasons. In contrast, Chlorophyta and Euglenophyta were permanently present in the all lakes and at all sampling seasons. However, Chlorophyta is poorly represented at lakes 1 and 7 and Euglenophyta at lakes 7, 9 and 10 at all sampling seasons.
Lake 0

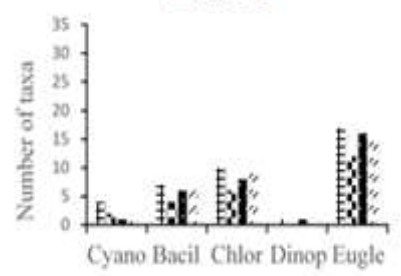

Lake 6

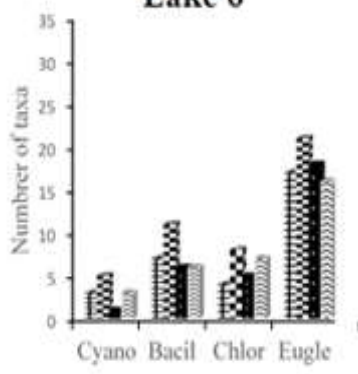

Lake 9

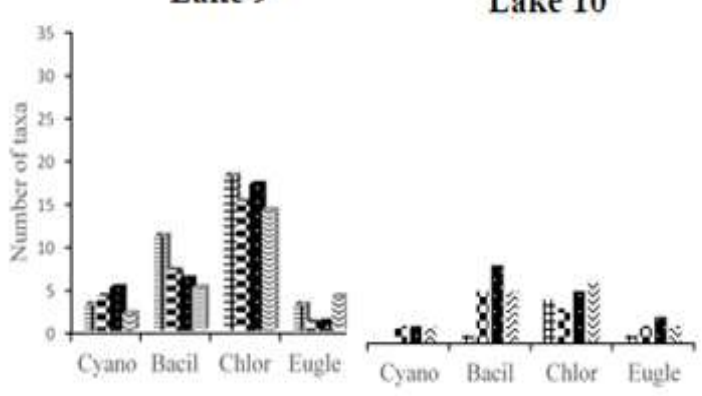

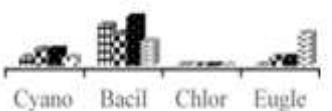

Cyano Bacil Chlor Eugle
Lake 5

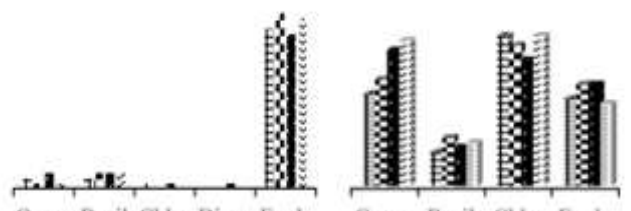

Cyano Bacil Chlor Dinop Eugle Cyano Bacil Chlor Eugle

Lake 7

Lake 8

Cyano Bacil Chlor Eugle

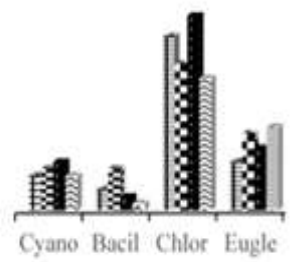

曲册 LDS

BQ SDS

LRS

竝氛 SRS

Figure 4: Spatio-seasonal in the taxonomic richness of the phytoplankton communities of the urban Yamoussoukro lakes. LDS=Long Dry Season. SDS=short Dry season. LRS=Long Rainy season. SRS= Short Rainy season, Cyano= Cyanobacteria, Bacil= Bacillariophyta, Chlor= Chlorophyta, Eugl= Euglenophyta, Dinop=Dinophyta 
Table 3: list of species to different groups formed by HCA in Yamoussoukro urban lakes

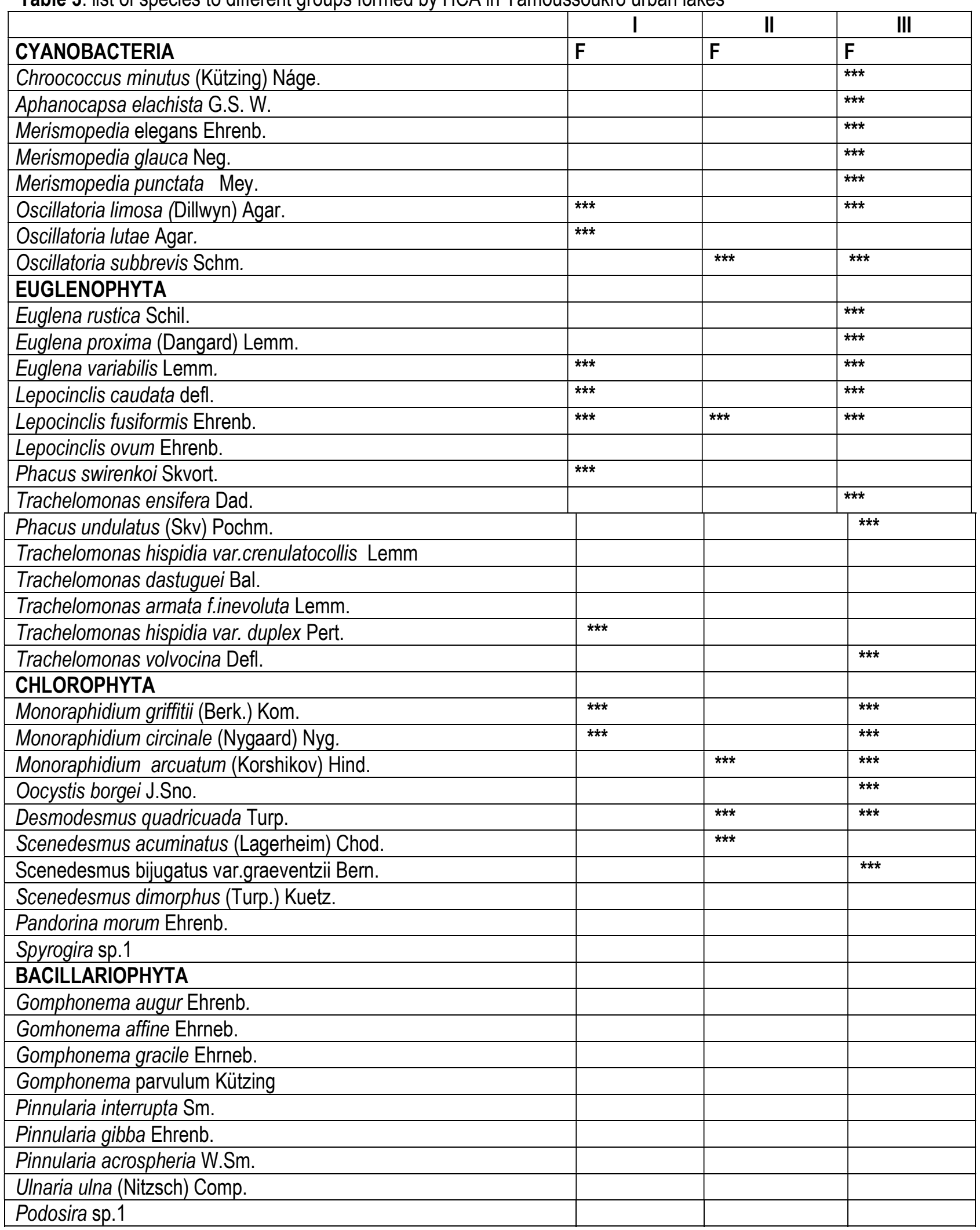

${ }^{* * *}$ constant species, F: Frequency 


\section{DISCUSSION}

The mean values of conductivity, nitrates and nitrites were high at the lake 7 and there is significant difference in the conductivity and nitrate between Lake 7 and others lakes. Indeed, the Lake 7 is situated close to a much-inhabited zone, thus it receives the most quantity of wastewater with a high organic content and sediments. Besides, this lake presents the smaller surface, the processes of dilution of the pollutants are few intense. That favour high concentration of nutriments and high conductivity in this lake compared to the others lakes. Mean values of the orthophosphate, dissolved oxygen, and ammonium were slightly higher at the lake 8, than in the others lakes. The high values of dissolved oxygen are due to the strong dissolution of atmospheric oxygen in this ecosystem, whose surface is permanently cleared of its aquatic vegetation (Parinet et al. 2000). The high level of ammonium and Orthophosphates can be explained by the contribution of domestic wastewater and runoff that carry nutrients in the watershed. Moreover, the high values of the other environmental variables would be due to the anthropic pressure. Indeed, the man-made lakes of Yamoussoukro received important quantities of erosion products and waste (domestic waste, oil, sewage, sludge drain), and significant quantities of wastewater and solid waste. According to N'guessan et al. (2011), these urban lakes received about $38300 \mathrm{~m}^{3}$ of wastewaters (black waters, gray waters, sludges) annually. In addition, the nearby agricultural activities and use of chemical fertilizers is at the origin of a large spill of nutrients in the various lakes. The phytoplankton communities found in urban man-made lakes of Yamoussoukro can be considered as rich in the number of taxa (196 taxa). This richness may be related to the fact that the waters of the lakes are stagnant. Indeed, the development of phytoplankton communities is highly dependent on the stability of the water column. In addition, the stagnant nature of the lakes promotes biological processes such as complete cycles of reproduction and development of algae (Ouattara, 2000). Besides this richness could be due to less depth of the lakes, allowing lighting of substantially the entire water column, in fact, light plays an important role in the growth, diversity and density of

\section{ACKNOWLEDGEMENTS}

The authors would like acknowledge "SODERTOUR LAC" and Fishing and Aquaculture pole of Nangui aquatic flora. Algal growth has been reported to increase with light intensity, and luminescence was found most favorable (Shen, 2002). The assemblage of phytoplankton is dominated by the Chlorophyta and Euglenophyta. The high number of Chlorophyta is due to high diversity of Chlorococcals (60 taxa) observed in this group. In addition, the physical and chemical characteristics of lakes are favorable for a specific diversification of Chlorophyta. Indeed the Chlorophyta are typically thermophilous and photophilic (Cabioc'H et al. 1992; Sheath and Wehr, 2003). As to Euglenophyta, its diversity could be explained by the impact of external and internal flows in the lakes so the organic matter available (Kim and Boo, 1998; Dia and Reynaud, 1982). The genera like Trachelomonas and Scenedesmus dominated the taxonomic richness, because these genera were growing in waters with a high organic matter content. The high quantity of organic matter comes from to toilets sewage and wastewater from hotels, restaurants, hospital, markets and agricultural. The lake 5 was the most specific rich and the lake 7 poor. The high number of taxa in Lake 5 can be explained by the fact that it is located in the center of the city. It receives the waters of the lakes with the exception of the lake 6 located downstream. While the lake 7 was poor because it's considered as a receptacle of waste water of the town (Parinet et al.. 2000). Hierarchical cluster analysis presented three clusters. The third cluster contains the majority of lakes in the populated area receiving domestic and agricultural wastewater. The algal composition of lakes in cluster III is different from cluster I and II, because these lakes have higher mean Conductivity and salts ammonium value. However, the isolation of the lake 7 in the cluster II can be explained by the high average values of Conductivity and Nitrates. The grouping of sampling sites with similar algal assemblages showed that the type of pollution influenced communities. The phytoplankton composition of the different urban lakes of Yamoussoukro is different. This difference can be explained by the difference in physical and chemical parameters and nutrients.

Abrogoua University for their cooperation during the study 


\section{REFERENCES}

AFNOR, 2005. Recueil Normes et Réglementation Environnement. Qualité de l'eau, $552 \mathrm{p}$.

Ansari AA, Gill S S, Lanza G R, Rast W, 2011. Eutrophication: Causes. Consequences and Control. Springer: Dordrecht: 131-142.

Cabioc'h J, Floc'h JY, Le Toquin AA, 1992. Guide des algues des mers d'Europe. Delachaux et Niest lé (Eds), Paris: 1992, $231 \mathrm{p}$

Dajoz R, 2000. Précis d'écologie. Septième édit ion. Paris: Dunod, 2000, $615 \mathrm{p}$.

Desikachary, T. V., 1959. Cyanophyta. Indian Council of Agriculture research. Delhi, $689 \mathrm{p}$.

Dia A. \& Reynaud P A, 1982. Le phytoplancton du lac de Guiers: approche qualitative et quantitative. Cahiers O.R.S.T.O.M., série Hydrobiologie, 5: $35-47$.

Huber-Perstalozzi G, 1955. Das Phytoplankton des Süsswassers. Teil 4 Euglenophyceen. Stuttgart. 606 p.In: G. Huber-Pestalozzi (eds.). Das Phytoplankton des Süßwassers 7/1: $X$ +1044 p. 253 pl. 37.

Kim JT. \& Boo S M, 1998. Morphology, population size, and environmental factors of two morphotypes in Euglena geniculata (Euglenophyceae) in Korea. Archiv für Hydrobiologie, Supplement, 126: 27 - 36.

Komárek J. \& Anagnostidis K, 2005, Cyanoprokaryota2. Teil/ 2nd Part: Oscillatoriales. In: Büdel B. Gärtner G. Krienitz L. \& Schagerl M. (eds.): Süßwasserflora von Mitteleuropa 19/2. Elsevier. Heidelberg. 759 p.

Komárek J. \& Fott B, 1983. Chlorophyceae (Grünalgen) Ordnung: Chroococcales. In G. HuberPestalozzi (ed.), Das Phytoplankton des Sübwassers, 7 (1) 1 - $1044+253$ pl

Konan EM, Yaokokore-Beibro KH, Odoukpe KSG, Kouadja KES, 2014, Avifaune de la ville de yamoussoukro, centre de la Cote d'lvoire. European Scientific Journal, 10 (33): 63-73.

Konan EMI, Yaokokore-Beibro KH, Odoukpe KSG, 2015. Richesse spécifique et abondance des oiseaux des dix Lacs Urbains de la ville de Yamoussoukro, dans le centre de la Côte d'Ivoire. International Journal of Innovation and Applied Studies, 10: 217-225.

N'guessan K A, Konan Bony K F, Edia O E, Gnagne T, Traoré KS, Houenou PV, 2011. Prospects for rehabilitation of man-made lake system of Yamoussoukro (Ivory Coast). Procedia Environmental Sciences, 9: 140-147.
Kouakou KA., AW S, Adamou MM, Siaka S, Savane I., 2014, Caractérisation des sediments du systeme lacustre de yamoussoukro (Côte d'Ivoire) et speciation de leurs phosphores (characterization of sediments of yamoussoukrolake system (Côte d'Ivoire) and their phosphorus speciation). Journal and Mater and Environemental Sciences, 5 (4):1013-1020

Krammer K \& Lange-Bertalot H, 1991. Bacillariophyceae: Centrales.Fragilariaceae. Eunotiaceae. In: Ettl H. Gerloff J. Heying H. \& Mollenhauer D. (Eds.): Süßwasserflora von Mitteleuropa. Stuttgart. Fischer. 2 (3):576 p. $166 \mathrm{pl}$

Krammer K. \& Lange-Bertalot H, 1988. Bacillariophyceae 2. Teil: Bacillariaceae, Epithemiaceae, Surirellaceae. Süßwasserflora von Mitteleuropa, G. Fischer Verlag, Stuttgart, 2/2, $596 p$

McQuatters-Gollop A, Gilbert AJ, L. Mee D, Vermaat JE, Artioli Y., Humborg C, Wulff F, 2009. How well do ecosystem indicators communicate the effects of anthropogenic eutrophication Estuary Coastal and Shelf Science 82 (4): 583-596

Naselli-Flores L, 2014. Morphological analysis of phytoplankton as a tool to assess ecological state of aquatic ecosystems: The case of Lake Arancio. Sicily. Italy. Inland Waters, 4: 15-26.

Naselli-Flores L, 2011. Mediterranean climate and eutrophication of reservoirs: limnological skills to improve management. In Ansari. A. A. S. S. Gill. G. R. Lanza \& W. Rast (eds). Eutrophication causes, conséquences and control. Springer, Dordrech, 131-142.

Ouattara A, 2000. Premières données systématiques et écologiques du phytoplancton du lac d'Ayamé (Côte d'Ivoire). Thèse de doctorat, Katholieke Universiteit Leuven, Belgique, $207 \mathrm{p}$.

Paerl HW, Xu H, McCarthy M J, Zhu G, Qin B, Li Y, Gardner S.W, 2011. Controlling harmful cyanobacterial blooms in a hyper-eutrophic lake (Lake Taihu. China): the need for a dual nutrient (N \& P) management strategy. Water Research, 45: 1973-1983.

Parinet B, Lhote A, Legubé B, Gbongué M A, 2000. Etude analytique et statistique d'un système lacustre soumis à divers processus 
d'eutrophisation. Revue sciences de l'eau, Revue Sciences et Eau, 13(3): 237-267

Shen D S, 2002. Study on limiting factors of water eutrophication of the network of rivers in plain. Journal of Zhejiang University (Agriculture and Life Sciences), 28(4): 94-97.

Sheath RG. \& Wehr JD, 2003. Freshwater Algae of North America. Ecology and classification. California, U.S.A, 918 p.

Spatharis S, Danielidis DB, Tsirtsis G, 2007. Recurrent Pseudo- nitzschia calliantha (Bacillariophyceae) and Alexandrium insue- tum (Dinophyceae) winter blooms induced by agricultural runoff. Harmful Algae, 6 (6): 811-822.
Tomas CR, 1995. Identifying Marine phytoplankton. Academic Press. Harcourt, 598p.

Uusitalo L,Fleming-Lehtinen V., Hällfors $\mathrm{H}$, Jaanus A, Hällfors S, London L, 2013. A novel approach for estimating phytoplankton biodiversity. ICES Journal of. Manine. Sciences, 70 (2): 408-417.

Van den Hoek C, Mann DG, Jahns HM, 1995. Algae. An introduction to phycology. Cambridge University Press. Cambridge. UK, 623 p.

Zar JH, 1999. Biostatistical Analysis. 4th Edition. Prentice-Hall, Englewood Cliffs, New Jersey, $662 p$. 